\title{
ゆでめんの製造法改良に関する研究
}

\section{（第 2 報）ゆで条件とゆで時の溶出損失}

\author{
柴田茂久*・豊島 英 親*・古堂久美子*
}

\author{
Improvement of Boiled Noodle (Udon)-Making
}

Part II. Material loss in boiling process of noodle (udon)-making

\author{
Shigehisa Shibata*, Hidechika Toyoshima* and Kumiko Kodô*
}

\begin{abstract}
In order to improve the boiling process of raw noodle, to increase the yield of product, and to reduce BOD load in waste water from the noodle factory, experiments were performed on the material loss during boiling raw noodle in hot water, in relation to the previous work of the processing conditions reported in Part I. The chemical composition of solid substance in the boiling water was also analized. The following results were obtained:

1) Material loss increased rapidly in several minutes after begining of boiling, and increased in proportion to the boiling time.

2) In cooking, material loss was minimum at $98.5^{\circ} \mathrm{C}$ and increased slightly at the other temperature.

3) The repeating use of boiling water caused increase of the concentration of dissolved matter and decrease of the material loss. Close correlation between the concentration of dissolved matter in boiling water and the material loss was confirmed.

4) Increase of the qantity of raw noodle in a batch process at boiling gave a slight decrease of material loss.

5) The solid substance of [the boiling water consist with more than $50 \%$ starch and the quantity increased as increasing the boiling time. The quanity of low molecular substance such as salt and reducing sugar was detected at the early stage.

6) By the examination of waste water from small-scale noodle factories having different boiling equipment as well as various condition of boiling, much differences were found in the concentration and composition of solid matter.

(Received Oct. 29, 1975)
\end{abstract}

ゆでめんの製造の廃水処理対策の一つとして, 製造方

法とゆで時の溶出損失の実態を明らかにし，廃水に流出

する污濁物質を少なくするように，製造工程を改良する

ことは重要である。との観点から，前報1にたいて生め

え製造条件とゆで時の溶出損失の関係について明らかに

した。今回はゆで条件と溶出量の関係について検討した ので報告する。

\section{実 験 方 法}

\section{1. 製めん条件}

前報1に示した標準の方法を用いた。概略は下記のと

\section{おりである。}

1) 原料粉

前報1 に用いた市販の同一銘柄のめん用粉 No. 1 と No. 2 および強力粉亡薄力粉である。さらに市販のめん 用粉 No. 4 安用い，その性状を Table 1 に示した。め ん用粉はすべて同じ会社の同じ銘柄の粉である。

2) 加塩量

粉に対して $2 \%$ とした。

3) 加水量

粉（14\% 水分ベース） 100 に対して水 31.7 を加光 た。これで生地の水分の計算值は $34.7 \%$ となる。

*農林省食品総合研究所（東京都江東区塩浜 1-4-12）

National Food Research Institute, Ministry of Agriculture and Forestry. Koto-ku, Tokyo. 
Table 1. Properties of flour No. 4

\begin{tabular}{|c|c|c|c|c|c|c|c|c|c|c|}
\hline \multicolumn{4}{|c|}{ Farinogram } & \multicolumn{4}{|c|}{ Extensogram } & \multicolumn{2}{|c|}{ Amvlogram } & \multirow[t]{2}{*}{$\begin{array}{c}\text { Crude } \\
\text { protein (\%) }\end{array}$} \\
\hline $\mathrm{Ab}(\%)$ & $\mathrm{DF}(\mathrm{m} 1 \mathrm{n})$ & Wk (B.U) & $\mathrm{VV}$ & $A\left(\mathrm{~cm}^{2}\right)$ & R (B.U) & $E(\mathrm{~mm})$ & $\overline{R / E}$ & $\mathrm{MT}\left({ }^{\circ} \mathrm{C}\right)$ & $\mathrm{MV}$ (B.U) & \\
\hline 56.6 & 2.5 & 5 & 58 & 123 & 485 & 183 & 2.65 & 88.3 & 755 & 9.65 \\
\hline
\end{tabular}

Flour No. 1, No. 2 and No. 4 is same brand.

Properties of flour No. 1 No. 2 was reported in Part 11) previously.

* $13.5 \%$ Moisture basis.

4）圧延

ロール間隙 $2 \mathrm{~mm}$ で 4 回, 切妇は No. $10(3 \mathrm{~mm}) を$ 用いた。

\section{2. ゆで試験}

ゆで温度の試験以外は前報”に示した標準の方法を用 いた。概略は下記のとおりである。ゆで方法は生めえ $76 \mathrm{~g}$ (乾物として約 $50 \mathrm{~g}$ ) に1lの水を加え, 微量の消 泡用シリコンを滴下し，ゆで試験器でゆでた。シリコン はゆで終了後直ちにゆでめんを取り出す際の発泡を防ぐ ためである。ゆで時の溶出損失は生めん乾物に対する百 分率で表わした。製めんの際加塩（粉に対して $2 \%$ ）し ているため，この溶出損失中に食塩が含まれている。ま たゆでめんの水分が 76\% になる時間を標準ゆで時間と し，25 分と 40 分のゆでめんの水分から求めた。ただ し，繰返しのゆで試験においてはゆで後 $1 l$ に定容し， 溶出物量測定の試料を $50 \mathrm{~m} l$ 採取してから, 再び $1 l$ に 定容して次のゆで試験に供した。

コントロールが難しい $100^{\circ} \mathrm{C}$ 以下の温度は次の方法を 用いた。ガラスの容器に恒温循環装置を付けゆで液を ゆるく一定速度で攪拌しながら所定の温度とした。容器 内に装置が入っているため水量を多くし， $2 l$ の水で $76 \mathrm{~g}$ の生めん（乾物として約 $50 \mathrm{~g}$ ）をゆでた。

\section{3.ゆで時の溶出物組成}

ゆで液 $300 \mathrm{~m} l$ （濃度は $0.5 \sim 2.0 \%$ ）に同量の無水工 タノールを加え，全体を $50 \%$ エタノール濃度として一 夜低温 $\left(5 \sim 8^{\circ} \mathrm{C}\right)$ に放置後沪別した。

\section{1) 沈澱物}

減圧乾燥後重量を求め，港粉質 $(50 \%$ エタ)ール沈激 物）とした。この区分には蛋白質の一部や瀻維も沈激し ているが，量的にわずかであり，ほとえどが激粉および 高分子のデキストリンである。

2) 沪液

沪液は湯浴上でエタノールを蒸発後定容し, $150 \mathrm{ml}$ を 三角フラスコに取り， $25 \%$ 塩酸 $20 \mathrm{ml}$ を加え量流冷却 管を付け湯浴上で 2 時間 30 分加水分解した。分解液は SOMOGYIの変法により還元力を測定し，それから直糖の 量元力を差し引いてグルコース量を求め，0.9を莱じて
デキストリンとした。この区分はデキストリンおよび非 還元性糖である。

3) 直接遗元糖

沪液の一部を SOMOGYI の変法を用いて定量し，マル トースとして計算した。

\section{4. ゆで液の粘度}

オストワルド粘度計を用い， $25^{\circ} \mathrm{C}$ で測定し純水と比 較して相対粘度とした。

5. ゆで液の粗蛋白質, 食塩および pH

1) 粗蛋白質

ケルダール法により， $\mathrm{N} \times 5.7$ で粗蛋白質を求めた。

2）食塩

モール法で測定した。

3) $\mathrm{P} \mathrm{H}$

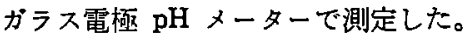

\section{実験結果と考察}

\section{1. ゆで時間}

めんを一定時間ゆでた際の溶出量は小麦粉の性状およ

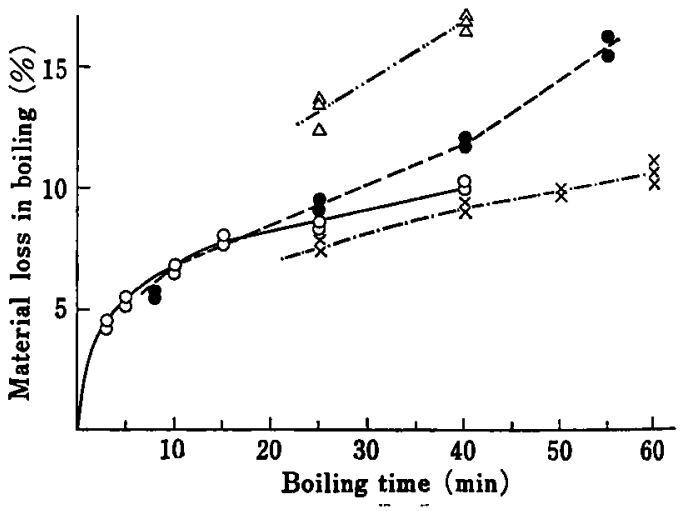

Fig. 1. Relationship between boiling time and material loss in boiling

Standard boiling time

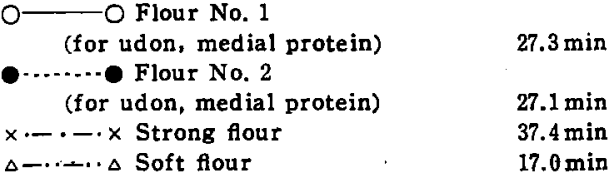


びめえの太さによって大きく異なってくることは前報1 で述べたとおりである。ここではゆで時間と溶出の状態 について検討し, Fig. 1 に結果を示した。めん用粉 No. 1 の例をみると，始めの数分から 10 分位までは急激に 溶出量が増加するが，その後は線が直線に近ゔきほぼゆ で時間に比例して溶出量が增加することがわかる。さら にめえ用粉 No. 2 の線が示すように，ゆで時間が長く なり過ぎるとまた溶出量が急に増加する。この場合強力 粉のめんはゆで時間が長くなっても Fig. 1 に示すよう に楾の勾配㹥わらないで，ゅで時間と溶出量の比例関 係が続いている。薄力粉のめんは溶出損失が大きく，ゆ で時間と溶出量の関係の公配が急になっている。また標 準ゆで時間は Fig. 1 の下に示すように粉によって大き く異なっている。このように小麦粉の種類，すなわちグ ルテンの含量によってめんのゆで状態が変わることがわ かった。

\section{2. ゆで温度}

95，97，98.5 および $101.3^{\circ} \mathrm{C}$ の温度における標準ゆ で時間と溶出量の関係を Fig. 2 に示した。ゆで温度と 標準ゆで時間は明らかな相関が認められ，時間，温度が $1^{\circ} \mathrm{C}$ 低くなると，ゆで時間は 1.45 分長くなる(回帰直線 $y=-1.45 x+175.1, \gamma=-0.967$ 加計算)。溶出損失 は $98.5^{\circ} \mathrm{C}$ の試験区が最低を示し, それ以外は温度の上 下によりわずかであるが溶出量が増加する傾向を示し た。ゆで温度が $95^{\circ} \mathrm{C}$ の試験区はゆでめんにやや異臭を 認めた。

これらの結果および高い温度は発泡によるオーバーフ ローがあることを考えると，最適ゆで温度は $99^{\circ} \mathrm{C}$ 位と 推定できる。

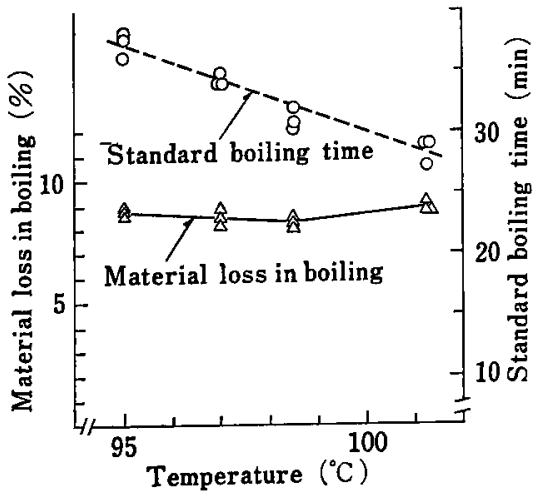

Fig. 2. Boiling temperature and its influence on the material loss in boiling and standard boiling time

Used flour is No. 4

\section{3. ゆで用水中の溶出物の濃度（ゆでる前）}

ゆでめんの工場においては，ゆで槽の水は 1 回ごとに 取替えず，繰返し使用している。そのためにゆでめえ製 造中に河で槽の用水中の溶出物はだんだん祳くなってい き，それは製造終了時にかなりの濃度々なっている。た とえば 2 槽式のゅで槽の上段槽のゆで廃水は蒸発残査 $3.83 \%$ ，その中の強熱減量が $2.64 \%$ という報告 ${ }^{2)}$ があ る。そとで繰返して用いるゆで用水中の溶出物の濃度と 溶出損失の関係について試験した。で用水を繰返して 使用し， 25 分および 40 分のゆで 試験をしたところ， Fig. 3 亿示すようにゆで用水中の溶出物の浱くなると

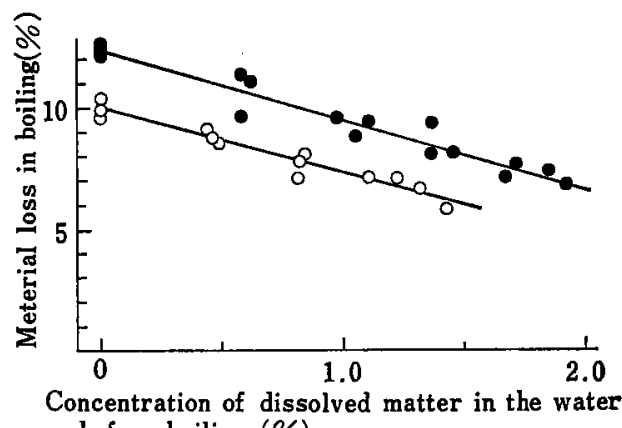
before boiling (\%)

Fig. 3. Effect of concontration of dissolved matter in the water before boiling on the material loss in boiling

$O$ boiling time, $25 \mathrm{~min}$.

Used flour is No. 2

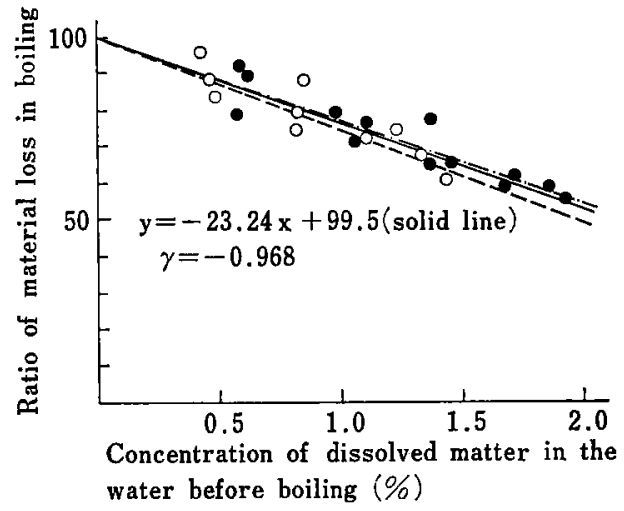

Fig. 4. Relationship between concentration of dissolved matter in the water before boiling and ratio of material loss in boiling

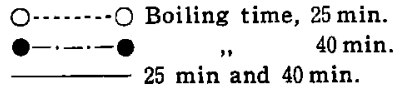
Used flour is No. 2 


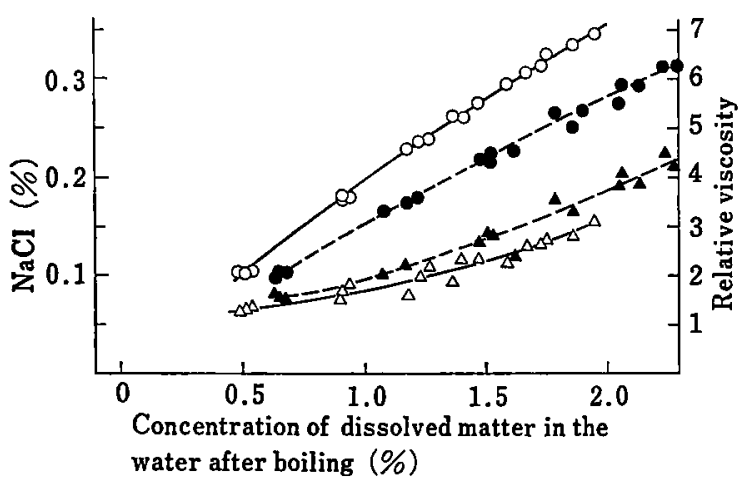

Fig. 5. Relationship between concentration of dissolved matter in the water after boiling and $\mathrm{NaCl}$ content or relative viscosity $\mathrm{O}-\mathrm{O} \mathrm{NaCl}$, boiling time, $25 \mathrm{~min}$.

- $\mathrm{NaCl}, \quad \quad 40 \mathrm{~min}$.

$\triangle-\triangle$ Relative viscosity, boiling time, $25 \mathrm{~min}$.

$\Delta-\Delta$ Relative viscosity, borling time, $40 \mathrm{~min}$.

Used flour is No. 2

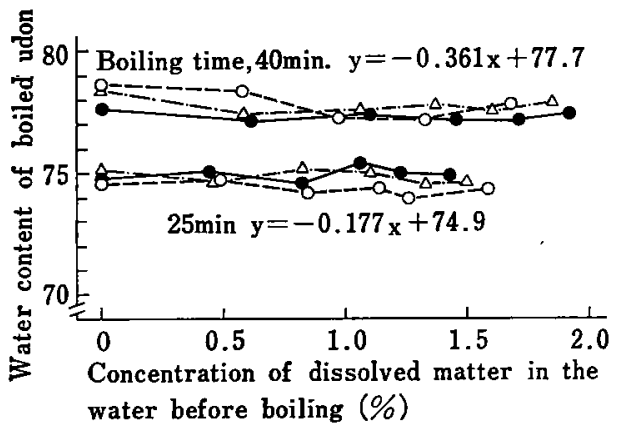

Fig. 6. Concentration of dissolved matter in the water before boiling and its influence on the state of boiled udon

The state of boiled udon was expressed percent of water content after boiling Used flour is No. 2.

溶出量が減少し,ゆで用水中の溶出物の莀度と溶出損失 は非常に高い負の相関を有することがわかった。溶出損 失は Fig. 1 にあるようにゆで時間によって異なるし， また原料粉の性状によって異なることはすでに前報”に おいて詳しく述べたとおりである。そこで純水（浘度 0) を用いた際の溶出損失を 100 とし, 溶出量の相対的な减 少の状態を Fig. 4 に表わした。Fig. 4 に示されている ようにゆで 25 分および 40 分むほほ同じ勾配を示して いる。さらに両者を合わせた回帰直線（Fig. 4 の実線） は, $y=-23.24 x+99.5$ の式 ( $y$ は溶出損失の減少比率, $x$ はゆで用水中の溶出物濃度) で表わされ， $\gamma=-0.968$ と高い負の相関を示すことがわかった。ゆでを繰返すこ

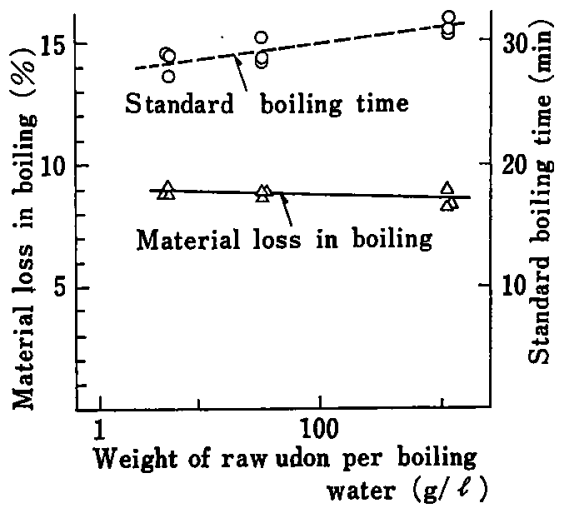

Fig. 7. Weight of raw udon per doiling water and its influence on the material loss in boiling and standard boiling time Used flour is No. 4.

とにより，中で夜の粘度および食塩濃度が上䒜するがそ の状態を Fig. 5 に示した。4〜5 回の繰返しによりか なりの濃度となるがゆで繰作に特に問題はなかった。

ゆで液中の溶出物の濃度が濃くなると，めん線内に熱 と水の浸透が悪くなり，更でが非常に遅くなるという説 もある。しかしこれについて疑問を感じ，一定時間ゆで た場合にゆで用水中の溶出物濃度がゆで上りの状態にど のように影響するか検討してみた。ゆで上り状態はゆで めんの水分量でチェックした。各種のゆで用水中の溶出 物の濃度で 25 分および 40 分と一定時間でゆでた場合, ゆで用水中の溶出物の濃度の影響を Fig. 6 に示した。 これによると，ゆで用水中の溶出物濃度が $2.0 \%$ で，25 分ゆでた場合ですゆでめん水分が対照に比べて $0.35 \%$ 低くなる程度である。この $0.35 \%$ の水分を増加するゆ で時間は 1.4 分であるから，それだけゆで上りがおそく なったことになる。今回のめん用粉のめんの標準ゆで時 間 29 分からみると，ゆで時間があずか $5 \%$ おそくなっ ハのにすぎない。

\section{4. ゆで液に詨する生めんの量}

ゆでに際して，湯量に対して投入生めん量が多過ぎる そゆで時間の延長およびめん線のこすれ合いによるは だ荒れや溶出損失の 增加が生じると一般にいわれてい る。ゆで時の湯量に対する生めん量の影響を Fig. 7 に 示した。ゆで液に対する生めん量は $38,76,152 \mathrm{~g} / l$ で あり，生あえに対しそれぞれ 26.3，13.2,6.6 倍の水で ゆでたことになる。Fig. 7 で明らかなように生めん量 38，76，152 g/l がと多くなると標準ゆで時間は 28.2, 29.2，31.1 分と僅かつつ長くなった。これは生めんを 湯に投下した際の晹温低下が生めん量に比例し, 生め? 
量が多いと再び沸腾するのに 時間ががかるためである 亏。

溶出損失は生めえ量が $38,76,152 \mathrm{~g} / l$ と多くなると $8.95,8.80,8.55 \%$ とやや減少した。これは生めえ量 が多くなると，溶出物の総量が多くなり，前述したよう にゆで液中の溶出物濃度が高くなるため溶出量が減少し たと考えられる。

\section{5. 溶出物の組成}

標準ゆで時間の溶出物の組成を Table 2 に示した。 原料粉中の還元糖、 $0.16 \%$ (グルコースとしての值。 マルトースとすると $0.29 \%$ となる）である。BLISH によると小麦粉中の還元糖注 $0.04 \sim 0.19 \%$ 位で, 平均 して $0.14 \%$ ，その他の例4 6) でも $0.11 \sim 0.15 \%$ 位であ る。非還元糖 ${ }^{8)}$ は $1.25 \%$ 位含まれるといわれる。デキ ストリンは小麦粒中に $0.1 \sim 0.2 \%{ }^{7}$ 舍まれるといるれ る。ところが Table 2 の組成をみると溶出物中の直接 還元糖(マルトースとして)は 13\% で，高い比率を占め ている。原料粉中の $0.29 \%$ の還元糖（マルトースとし て）が全部溶出しても, 全溶出量から計算すると溶出物 中では $2.96 \%$ にしかならない。このことはゆでわん の製造中に粉中の丁ミラーゼおよび加熱操作などによっ て澱粉および非還元糖などの分解がおこり，低分子のデ キストリンおよび直接還元糖が増加していること, さら にそれらの低分子の糖は溶出し易いためであると考え た。

原料小麦粉(乾物)中の粗蛋白質は $9.6 \%$ であるが, 溶 出物組成(食塩を除く) 中では $5.7 \%$ に減少している。 Fig. 8 に溶出量および 組成が経時的に変化する状態を 示した。食塩はゆで 8 分で全溶出量の $76 \%$ が溶出し,

Table 2. Chemical composition of solid substance in used boilihg water

\begin{tabular}{lrr}
\hline \multicolumn{1}{c}{ Composition } & $\begin{array}{c}\text { In whole S.S. } \\
(\%)\end{array}$ & $\begin{array}{c}\text { In S.S. } \\
(\%)\end{array}$ \\
\hline Crude protein & 4.6 & 5.7 \\
Reducing sugar (as maltose) & 10.4 & 12.9 \\
Dextrin & 9.6 & 11.9 \\
Starch & 52.1 & 64.5 \\
(precipitate by 50\% Ethano1) & 19.2 & \\
NaCl & 4.0 & 5.0 \\
Others $^{\text {a) }}$ & & \\
\end{tabular}

- Material loss in boiling, expressed $76 \%$ water content basis of boiled udon, was $9.8 \%$.

- Used flour is No. 2.

- Approximate dimension of raw noodle (section), $3.2 \times$ $2.9 \mathrm{~mm}$ (used slitting rolls No. 10)

a) Total solids minus the sum of chemical analysis.
ゆで 25 分以後溶出量は同じで，早い時期に溶出するこ とがわかる。その後, 食塩はゆでめん中とゆで用水中に 平衡状態にあることが計算により推定された。粗蛋白質 は，ゆで 8 分の溶出量は $0.26 \%$ であるが， 55 分になる と $0.8 \%$ に増加している。しかしこれを食塩を際いた溶 出物組成の百分率でみると，6.6\% から $5.8 \%$ に低下し ている。

直接還元糖およびデキストリンの溶出量は経時的に増 加するが， 25 分以後の增加率は粗蛋白質より少ない。 ゆで 8 分と 55 分の溶出物組成の百分率は，直接還元糖 は $15.7 \%$ から 9.3\%へ，デキストリンは $12.4 \%$ から 7.0\% へとかなり低下している。

澱粉質のような高分子区分では，ゆで 8 分の溶出損失 は $2.59 \%$ であるが， ゆで 55 分になると $10.76 \%$ と 大幅に増加し，溶出物組成の百分率でも $65.3 \%$ から $77.5 \%$ へと増加している。Fig. 8 でも 40 分以後に澱 粉質が急增している状態がかかる。これはゆでが過度に なるとめんの表面から，澱粉質の離脱が多くなるためと 考えられる。

これまでの結果から食塩, 直接還元糖およびデキスト リンなど低分子の物ほど早く最初に溶出することがよく わった。また澱粉質はかで状態が過度になると急增する ことが認められた。

\section{6. 製めん工場のゆで液の分析}

東京都内の製めえ工場のゆで槽から採取した試料の分 析結果を Table 3 に示した。A社, B 社は小規模で, 横 型移行式ゆで槽(ハッチ式)の工場である。C社，D社は バスケットタイプの連続式ゆで槽（いわゆるオートメー

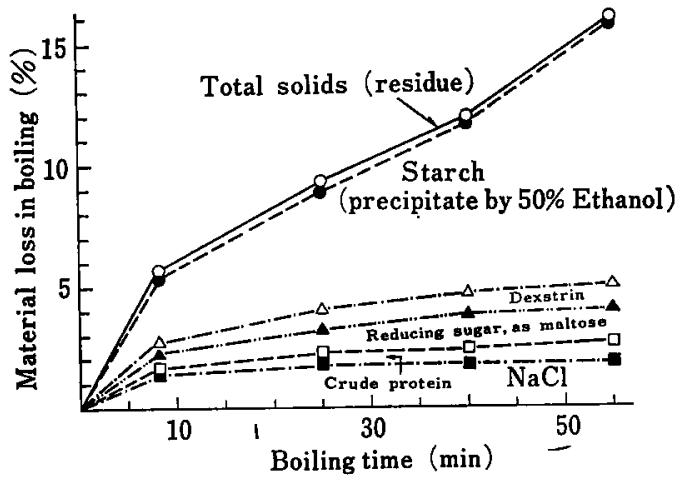

Fig. 8. Relationship between boiling time and composition

Approximate dimesion of raw noodle (section), $3.2 \times 2.9 \mathrm{~mm}$ (used stitting rolls No. 10)

$O$ Used flour is No. 2 (same data, Fig one's flour No. 2, dotted line) 
Table 3. Composition and component of waste water after boiling detected at a factory

\begin{tabular}{|c|c|c|c|c|c|c|c|c|}
\hline & \multicolumn{2}{|r|}{ A } & \multicolumn{2}{|r|}{ B } & \multicolumn{2}{|r|}{ C } & \multicolumn{2}{|r|}{ D } \\
\hline & $\mathrm{g} / 100 \mathrm{~m} l$ & $\begin{array}{l}\text { Component, } \\
\text { except } \mathrm{NaCl}\end{array}$ & $\mathbf{g} / 100 \mathrm{~m} l$ & $\begin{array}{l}\text { Component, } \\
\text { except NaCl }\end{array}$ & $\mathrm{g} / 100 \mathrm{~m} l$ & $\begin{array}{l}\text { Component, } \\
\text { except } \mathrm{NaCl}\end{array}$ & $\mathbf{g} / 100 \mathrm{~m} l$ & $\begin{array}{l}\text { Component, } \\
\text { except } \mathrm{NaCl}\end{array}$ \\
\hline Crude protein & 0.141 & 8.6 & 0.131 & 9.6 & 0.056 & 6.3 & 0.083 & 13.4 \\
\hline $\begin{array}{l}\text { Reducing sugar } \\
\text { (as maltose) }\end{array}$ & 0.219 & 13.3 & 0.206 & 15.0 & 0.132 & 15.0 & 0.107 & 17.3 \\
\hline Dextrin & 0.246 & 15.0 & 0.235 & 17.0 & 0.164 & 18.6 & 0.075 & 12.1 \\
\hline $\begin{array}{c}\text { Starch (precipitate } \\
\text { by } 50 \% \text { EtOH) }\end{array}$ & 1.035 & 63.1 & 0.797 & 48.4 & 0.530 & 60.1 & 0.355 & 57.3 \\
\hline $\mathrm{NaCl}$ & $\begin{array}{l}0.09 \\
(5.2)^{\mathrm{a})}\end{array}$ & & $\begin{array}{r}0.279 \\
(16.9) a)\end{array}$ & & $\begin{array}{c}0.103 \\
\left.(10.5)^{a}\right)\end{array}$ & & $\begin{array}{r}0.250 \\
(28.7)^{2}\end{array}$ & \\
\hline Total & 1.731 & 100.0 & 1.648 & 100.0 & 0.985 & 100.0 & 0.870 & 100.0 \\
\hline $\mathrm{pH}$ & 6.10 & & 6.40 & & - & & 6.25 & \\
\hline Total solids & 1.703 & & 1.633 & & 0.991 & & 0.890 & \\
\hline
\end{tabular}

$A$ and $B$, batch type boiling equipment. $C$ and $D$, continuous boiling equipment.

a) as percent in total component.

ション式) の比較的比較的大きな工場である。Table 3 ですぐわかるように,ゆで液中の溶出物の濃度は A, B の二社が濃く，C，Dの二社が薄く，約倍近くの差がある ことがわかる。これは $\mathrm{A}$ 社，B社のようなバッチ式ゆで 槽は容積が小さく，めんに対する湯量の比率が少ない状 態でゆでているためと考えられる。これに反してオート メーション式はゆで槽の容積が大きく，湯の量も多い。 ゆで液の成分では食塩の量がまちまちであり，ゆで液の 成分中の百分率恃 $\mathrm{A}$ 社の $5.2 \%$ か D 社 28.7 と大差が あった。これは生めん製造の際の食塩添加量が工場によ って大きく異なることを意味している。食塩を除いた組 成中の粗蛋白質はC社の $6.3 \%$ からD社の $13.4 \%$ と大 きな差違がある。これ注製品の構成(うどん，中華めん， そば)，原料粉の蛋白含量およびゆで時間(かんの太さが 関係する)が異なることが原因であるう。Table 2 に比 較するとまた食塩を除いた組成中に直接還元桾とデキス トリソが多く溉粉質が低い傾向を示している。ゆで時間

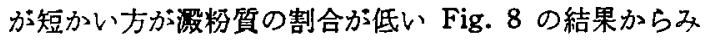
$て$, 調查した工場はこの試験の場合より，ゆで時間は短 かいと推定できた。

\section{要 約}

生めんのゆで条件とゆで時の溶出損失の関係およびゆ で液中の溶出物の組成を検討し, 次の結果を得た。

1）ゆで時間と溶出量の関係は，始めの数分量に溶出 量が急増するが，その後はゆで時間に比例して溶出量が 增加する傾向を示した。

2)ゆで温度と溶出量の関倸は $98.5^{\circ} \mathrm{C}$ が最低であり， それ以外は温度の上下によりわずかであるが溶出量が増
加した。

3）ゆで用水をくり返して使用し，溶出物の濃度が高 い状態でゆでると，溶出量が大きく減少することを認 め,ゆで用水中の溶出物の濃度と溶出損失は高い負の相 関を示すことがわかった。

4）ゆで液に対する生めんの量が多くなると, 溶出量 はやや減少することを認めた。

5）ゅで液中の溶出物組成中には搌粉質が半ば以上も 占め，その比率は時間の経過とともに増加する。食塩お よび直接還元糖などの低分子の物質は初期に多く溶出す ることがわかった。

6）製めん工場のゆで液の調査では, 各社のゆで槽の 構造およびめえの製造条件の差異から，ゆで液中の溶出 物の濃度およびその組成がかなり異なっていることを認 めた。

\section{文献}

1）柴田茂久 - 豊島英親-古堂久美子：摞粉科学, 20 , 183 (1973).

2）産業公害防止協会：農林水産業関係業種の公害防 止技術対策研究報告書 (1973).

3) Blish, SAndstedt and Astleford: Cereal Chem., 9, 378 (1932).

4) Косн, R. B., SMITH, F. and Geddes, W.F.: Cereal Chem., 31, 55 (1954).

5) Jongh, G. and HinTzEN, H. M.R.: Baker's Digest, 29, 41 (1955).

6）田中康夫 - 桑原一子・佐藤友太郎：食品工誌, 12, 184 (1965).

7）日本麦類研究会編：小麦粉，p. 173 (1965).

(昭和 50 年 10 月 29 日受理) 